\title{
The National Question in Yugoslavia
}

ORIGINS, HISTORY, POLITICS

\section{IVO BANAC}

Cornell University Press 
PUBLICATION OF THIS BOOK WAS ASSISTED BY A GRANT FROM THE PUBLICATIONS PROGRAM OF THE NATIONAL ENDOWMENT FOR THE HUMANITIES, AN INDEPENDENT FEDERAL AGENCY.

Copyright $\mathbb{C} 1984$ by Cornell University Press

All rights reserved. Except for brief quotations in a review, this book, or parts thereof, must not be reproduced in any form without permission in writing from the publisher. For information, address Cornell University Press, Sage House, 512 East State Street, Ithaca, New York 14850.

First published 1984 by Cornell University Press.

First printing, Cornell Paperbacks, 1988.

\section{Library of Congress Cataloging in Publication Data}

Banac, Ivo.

The national question in Yugoslavia.

Bibliography: $p$.

Includes index.

ISBN-1 3: 978-0-8014-9493-2 (pbk. : alk. paper)

ISBN-10: 0-8014-9493-I (pbk. : alk. paper)

I. Nationalism-Yugoslavia. 2. Yugoslavia-Politics and government1918-1945. I. Title.

$\begin{array}{llll}\text { DRI295.B36 } & 1984 & 949.7^{\prime} 02 & 83-45931\end{array}$

Cornell University Press strives to use environmentally responsible suppliers and materials to the fullest extent possible in the publishing of its books.

Such materials include vegetable-based, low-VOC inks and acid-free papers that are recycled, totally chlorine-free, or partly composed of nonwood fibers. For further information, visit our website at www.cornellpress.cornell.edu.

Paperback printing $\quad \begin{array}{lll}10 & 9 & 8\end{array}$ 
The National Question in Yugoslavia 

To my mother

Annoe autem dedit partem unam tristis, quia Annam diligebat. 
